\title{
The Effects of Sindbis Viral Vectors on Neuronal Function
}

\author{
Seçil Uyaniker ${ }^{1}$, Sophie J. F. van der Spek ${ }^{2}$, Niels R. Reinders ${ }^{1,3}$, Hui Xiong ${ }^{1,3}$, \\ Ka Wan Li², Koen Bossers ${ }^{1}$, August B. Smit ${ }^{2}$, Joost Verhaagen ${ }^{1,2}$ and \\ Helmut W. Kessels ${ }^{1,3 *}$ \\ ${ }^{1}$ Laboratory for Neuroregeneration, The Netherlands Institute for Neuroscience, Royal Netherlands Academy of Arts \\ and Sciences, Amsterdam, Netherlands, ${ }^{2}$ Department of Molecular and Cellular Neurobiology, Center for Neurogenomics \\ and Cognitive Research, Amsterdam Neuroscience, VU University Amsterdam, Amsterdam, Netherlands, ${ }^{3}$ Department \\ of Cellular and Computational Neuroscience, Swammerdam Institute for Life Sciences, Amsterdam Neuroscience, University \\ of Amsterdam, Amsterdam, Netherlands
}

Viral vectors are attractive tools to express genes in neurons. Transduction of neurons with a recombinant, replication-deficient Sindbis viral vector is a method of choice for studying the effects of short-term protein overexpression on neuronal function. However, to which extent Sindbis by itself may affect neurons is not fully understood. We assessed effects of neuronal transduction with a Sindbis viral vector on the transcriptome and proteome in organotypic hippocampal slice cultures, and analyzed the electrophysiological properties of individual CA1 neurons, at $24 \mathrm{~h}$ and $72 \mathrm{~h}$ after viral vector injection. Whereas Sindbis caused substantial gene expression alterations, changes at the protein level were less pronounced. Alterations in transcriptome and proteome were predominantly limited to proteins involved in mediating anti-viral innate immune responses. Sindbis transduction did not affect the intrinsic electrophysiological properties of individual neurons: the membrane potential and neuronal excitability were similar between transduced and non-transduced CA1 neurons up to $72 \mathrm{~h}$ after Sindbis injection. Synaptic currents also remained unchanged upon Sindbis transduction, unless slices were massively infected for $72 \mathrm{~h}$. We conclude that Sindbis viral vectors at low transduction rates are suitable for studying short-term effects of a protein of interest on electrophysiological properties of neurons, but not for studies on the regulation of gene expression.

Keywords: Sindbis viral vector, hippocampus, transcriptomics, proteomics, electrophysiology

\section{INTRODUCTION}

Viral vector mediated gene transfer is a commonly used approach in neuroscience to deliver genetic material into neurons. An effective gene delivery vehicle for neuronal cells is a recombinant Sindbis viral vector (Schlesinger, 1993; Malenka and Marie, 2006). Sindbis is an Alphavirus with a positive sense single-stranded RNA genome that allows a relatively large gene packaging capacity (up to $6.5 \mathrm{~kb}$ ) for proteins expressed under the control of a subgenomic RNA promoter. Recombinant, replication-deficient Sindbis virus-based vectors efficiently transduce neuronal cells (Gwag et al., 1998; Ehrengruber et al., 1999) and have been successfully used to express proteins of interest in neurons from dissociated cultures, organotypic slices and in vivo in order to study the cellular localization and function of these proteins (Maletic-Savatic et al., 1999; Osten et al., 2000; 
D’Apuzzo et al., 2001; Marie et al., 2005; Wang et al., 2011; Kebschull et al., 2016; Knafo et al., 2016; Reinders et al., 2016).

Sindbis viral vectors induce high levels of recombinant gene expression with a rapid onset: detectable levels of protein expression can be reached within 6 to $12 \mathrm{~h}$ after viral transduction (Gwag et al., 1998; Osten et al., 2000; D’Apuzzo et al., 2001). The levels of overexpression that can be achieved are substantial; for instance, Sindbis-mediated expression of AMPAreceptor subunits were approximately 5- to 10-fold increased relative to endogenously expressed AMPA-receptor subunits (Kessels et al., 2009). The fast induction and robust expression levels make Sindbis viral vectors highly suitable for studying effects of acute overexpression of a protein of interest on cell function, thus minimizing the risk of compensatory responses to the manipulation.

A concern for using the Sindbis virus-based expression system is its potential cytotoxicity. Although Sindbis viral vectors are less toxic to the host when the viral structural protein genes are deleted and only the gene of interest is expressed upon transduction, it can still cause shut-down of endogenous protein production within hours after transduction of heterologous cell lines (Bredenbeek et al., 1993; Frolov and Schlesinger, 1994). Possibly as a consequence of overwhelming the protein translation machinery, cytopathic effects begin to occur 30 to $48 \mathrm{~h}$ post-transduction (Bredenbeek et al., 1993; Frolov and Schlesinger, 1994). Post-mitotic neurons appear to be more tolerant toward recombinant Sindbis transduction: based on morphological and electrophysiological properties, hippocampal neurons transduced by Sindbis vectors remain viable for at least $48 \mathrm{~h}$ post-transduction (Ehrengruber et al., 1999; Maletic-Savatic et al., 1999; Marie et al., 2005; Kessels et al., 2009). However, the time course of potential disruptive events after transduction of neurons is not known. To obtain a complete picture of the state of a Sindbis transduced neuron, we set out to study the effects of Sindbis-mediated eGFP expression on the transcriptome, proteome, and electrophysiological properties of organotypic hippocampal slices at both 24 and $72 \mathrm{~h}$ post-transduction.

\section{MATERIALS AND METHODS}

\section{Preparation of Organotypic Hippocampal Slices}

All protocols were approved by the Animal Welfare Authority at the Dutch Central Committee for Animal Experimentation (NVWA). All experimental procedures were approved by the Institutional Animal Care and Use Committee of the Royal Netherlands Academy of Arts and Sciences (KNAW). C57BL/6 mice were used in this study. $400 \mu \mathrm{m}$ thick organotypic slices of the hippocampus were prepared from postnatal day 6-8 C57BL/6 mouse pups as described previously (Stoppini et al., 1991). After 7-12 days in culture for electrophysiology or after 8-9 days in culture for transcriptome and proteome analysis, Sindbis viral vector or PBS were injected into slices using glass pipets attached to a Picospritzer (General Valve, Fairfield, NJ, United States).

\section{Viral Vectors and Preparation}

pSinRep5-eGFP expression plasmid was used, and infective Sindbis pseudovirions were produced using the helper vector $\mathrm{pDH}-\mathrm{BB}$ according to the manufacturer's protocol (Invitrogen BV). In short: RNA was produced from pSinRep5-eGFP and $\mathrm{pDH}-\mathrm{BB}$ plasmids using mMESSAGE mMACHINE T7 Transcription Kit (Thermo Fisher Scientific). RNA was transfected into BHK-21 cell line by electroporation. After 48 h, Sindbis viral particles were isolated from BHK-21 supernatant through ultracentrifugation, resuspended in phosphate buffered saline (PBS) and stored at $-80^{\circ} \mathrm{C}$.

\section{Microarray Analysis}

Three organotypic slices were pooled and total RNA was isolated using RNeasy Mini Kit (QiaGen, Valencia, CA, United States) according to manufacturer's instructions. RNA concentration and purity were determined using a NanoDrop ND-1000 spectrophotometer (NanoDrop Technologies, Wilmington, DE, United States). RNA integrity (average RNA integrity number 9.1, SEM 0.14, range 7.5-10) was determined using the Agilent 2100 Bioanalyzer (Agilent Technologies, Palo Alto, CA, United States). Sample labeling and microarray hybridization were performed using Agilent 44K V2 Mouse Genome arrays according to manufacturer's instructions (Agilent Technologies, Part Number G4846A). Briefly, 60 ng RNA from each individual sample was used to simultaneously amplify sample material and synthesize cRNA that is fluorescently labeled with either Cy3-CTP or Cy5-CTP (Low Input Quick Amp Labeling Kit, Two-Color, Agilent Technologies.) Prior to hybridization, 825 ng of each Cy3-CTP- and Cy5-CTP-labeled cRNA were mixed. Specifically, each hybridization consisted of two individual samples from the same mouse, one transduced with Sindbis and one sham-treated and collected at the same time point post-injection. In the mixed samples RNA was fragmented for $30 \mathrm{~min}$ at $60^{\circ} \mathrm{C}$ in $1 \mathrm{x}$ Fragmentation Buffer (Agilent Technologies). The fragmented RNA samples were hybridized to a microarray by incubating for $17 \mathrm{~h}$ at $60^{\circ} \mathrm{C}$ in $1 \mathrm{x} \mathrm{Hi}$ RPM-Hybridization Buffer (Agilent Technologies) in a rotating hybridization chamber. After hybridization, the arrays were washed 6 times for $1 \mathrm{~min}$ each in saline-sodium phosphateEDTA (SSPE)/0.005\% N-Lauroylsarcosine (Sigma-Aldrich, St Louis, MO, United States), $1 \mathrm{~min}$ in $37^{\circ} \mathrm{C} 0.06 \mathrm{x}$ SSPE/0.005\% $\mathrm{N}$-Lauroylsarcosine and $30 \mathrm{~s}$ in acetonitrile (Sigma-Aldrich) at room temperature, then dried by nitrogen flow. Microarrays were scanned using an Agilent DNA Microarray Scanner at $5 \mathrm{~mm}$ resolution and $100 \%$ Photomultiplier tube setting. Microarray scans were quantified using Agilent Feature Extraction software (version 8.5.1). Raw expression data were imported into the $\mathrm{R}$ statistical processing environment using the LIMMA package in Bioconductor $^{1}$. All features for which one or more foreground measurements were flagged as saturated or as non-uniformity outlier by the feature extraction software, were excluded from further analysis. As overall background levels were very low, no background correction was performed. The intensity distributions within and between arrays were normalized using

\footnotetext{
${ }^{1}$ http://www.bioconductor.org
} 
the "quantile" algorithm in LIMMA. The log2-transformed intensity measurements per sample were used in all following analyses. To detect genes that are significantly up- or downregulated upon Sindbis transduction, student's $t$-test was used. Raw $P$-values were corrected for multiple testing using the Benjamini-Hochberg algorithm. For genes with FDR corrected $P$-values $<0.05$ and fold changes $(2$, a gene ontology overrepresentation analysis was performed using the PANTHER overrepresentation test (PANTHER version 13.1) PANTHER Pathways, Panther GO Slim Biological Process, PANTHER GO Slim Molecular Function and PANTHER GO Slim Cellular Component annotation datasets. Bonferroni correction was used for multiple testing. Gene Ontology classes with a corrected P-value of $<0.05$ were considered significant. Micro-array data are available upon request.

\section{Proteomics Analysis}

Snap-frozen organotypic slices (3 per group) were homogenized in ice-cold homogenization buffer $(0.32 \mathrm{M}$ Sucrose, $5 \mathrm{mM}$ HEPES, pH 7.4) containing "cOmplete" protease inhibitor cocktail (Roche Applied Science, Indianapolis, IN, United States) with a glass hand homogenizer (12 strokes). Protein concentration was determined using a Bradford Assay. Subsequently SDS loading buffer was added to the samples. Sample complexity was reduced by separating $30 \mu \mathrm{g}$ of protein per sample on molecular weight using a $10 \%$ SDS polyacrylamide gel. The gel was fixed overnight in fixation buffer (50\% Ethanol and 28\% Phosphoric Acid), washed three times in water and stained with Colloidal Coomassie Blue. Each sample was cut into two slices, the gel pieces were destained using $50 \mathrm{mM}$ $\mathrm{NH}_{4} \mathrm{HCO}_{3}$ and acetonitrile, and the proteins were digested with trypsin (sequence grade; Promega, Madison, United States) in a MultiScreen- HV 96 well plate (Millipore) overnight at $37^{\circ} \mathrm{C}$. Finally, the peptides were extracted from the gel pieces using $0.1 \%$ Trifluoroacetic acid in 50\% acetonitrile, and $0.1 \%$ Trifluoroacetic acid in $80 \%$ acetonitrile. The peptides were dried in a SpeedVac and stored at $-20^{\circ} \mathrm{C}$ until further use. For HPLC-ESI MS/MS analysis, the TripleTOF $5600+$ MS was coupled to an Ultimate 3000 LC system (Dionex). The samples were re-dissolved in mobile phase A (2\% acetonitrile and $0.1 \%$ fluoroacetic acid), then loaded and trapped on a $5 \mathrm{~mm}$ Pepmap 100 C18 column (300 $\mu \mathrm{m}$ id, $5 \mu \mathrm{m}$ particle size, Dionex). Next, peptides were fractionated on a Alltima C18 homemade column (300 $\mu \mathrm{m}$ id, $3 \mu \mathrm{m}$ particle size), using a linear gradient of increasing concentration of mobile phase B (99.9\% acetonitrile and $0.1 \%$ fluoroacetic acid) from $5 \%$ to $22 \%$ in $88 \mathrm{~min}$, to $25 \%$ at $98 \mathrm{~min}, 40 \%$ at $108 \mathrm{~min}$, and to $95 \%$ at $110 \mathrm{~min}$. After $8 \mathrm{~min}$. the column was back equilibrated to the initial condition of $5 \%$ acetonitrile for $10 \mathrm{~min}$. Peptides were electrosprayed into the mass spectrometer using an ion spray voltage of $2.5 \mathrm{kV}$, Gas1 and Gas 2 at 15 p.s.i., curtain gas at 25 p.s.i., and an interface heater temperature of $150^{\circ} \mathrm{C}$. The MS survey scan ranged from $\mathrm{m} / \mathrm{z} 350-1250$ acquired for $200 \mathrm{~ms}$. The top 20 precursor ions were selected for $100 \mathrm{~ms}$ per MS/MS acquisition, with a threshold of 100 counts and an exclusion window of 16s. Rolling CID function was activated, with an energy spread of $15 \mathrm{eV}$, and the subsequent MS/MS scan ranged from m/z 200-1800.
Finally, the MS/MS spectra were searched against the Mouse (UP000000589_10090 and UP000000589_10090_additional) and Sindbis (UP0000006710_11034) database using the MaxQuant software (version 1.5.2.8). The search parameters were set to trypsin digestion, the rest was kept at default. The mass spectrometry proteomics data have been deposited to the ProteomeXchange Consortium via the PRIDE (Perez-Riverol et al., 2016, 2019; Deutsch et al., 2017) partner repository with the dataset identifier PXD013634.

\section{Electrophysiology}

Organotypic hippocampal slices were perfused with ACSF (in mM: $118 \mathrm{NaCl}, 2.5 \mathrm{KCl}, 26 \mathrm{NaHCO}_{3}, 1 \mathrm{NaH}_{2} \mathrm{PO}_{4}, 4$ $\mathrm{MgCl}_{2}, 4 \mathrm{CaCl}_{2}$, and 20 glucose) gassed with $95 \% \mathrm{O}_{2} / 5 \%$ $\mathrm{CO}_{2}$. Whole-cell voltage-clamp recordings were made with 3 to $5 \mathrm{M} \Omega$ pipettes, and recordings were used when $R_{\text {access }}<20 \mathrm{M} \Omega$, and $R_{\text {input }}>10 \times R_{\text {access }}$. For mEPSC recordings, an internal solution was used containing (in mM) $115 \mathrm{CsMeSO}_{3}, 20 \mathrm{CsCl}, 10 \mathrm{HEPES}, 2.5 \mathrm{MgCl}_{2}, 4 \mathrm{Na}_{2}-$ ATP, 0.4 Na-GTP, 10 Na-Phosphocreatine, and 0.6 EGTA. Miniature EPSCs were recorded clamping at $-60 \mathrm{mV}$ with $1 \mu \mathrm{M}$ TTX and $50 \mu \mathrm{M}$ picrotoxin added to the bath, and were analyzed with the Mini Analysis program (Synaptosoft) with a minimum amplitude threshold of $5 \mathrm{pA}$. Neuronal excitabilities were recorded with internal solution containing (in $\mathrm{mM}$ ) $130 \mathrm{~K}$-gluconate, $20 \mathrm{KCl}, 4 \mathrm{Mg}$-ATP, $0.3 \mathrm{Na}$ GTP, 10 HEPES, and 10 Na2-phosphocreatine. Current step recordings were analyzed with Clampex 10.7 (Molecular Devices). The average sag ratio was calculated from the -100 $\mathrm{pA}$ current injection as $\left(1-\Delta \mathrm{V}_{s s} / \Delta \mathrm{Vmin}\right) \times 100 \%$, where $\Delta$ Vss $=$ Vrest - Vsteady state and $\Delta$ Vmin $=$ Vrest - Vminimum. All data were acquired using a Multiclamp 700B amplifier (Molecular Devices).

\section{RESULTS}

\section{Effects of Sindbis-GFP Transduction on the Transcriptome}

To examine whether Sindbis viral vectors influence gene expression in hippocampal neurons, we prepared cultured organotypic slices of hippocampi from C57BL/6 mice. Half of the slices prepared from each mouse were injected with a buffered solution containing Sindbis viral vector coding eGFP and the other half with a control solution. Slices were transduced with the viral vector to have the majority (50$100 \%$ ) of neurons express GFP. We isolated total RNA from the slices at 24 or $72 \mathrm{~h}$ after transduction. The integrity of isolated RNA was high and comparable between groups (average RIN: $9.1 \pm 0.14$ ). Copy RNA was synthesized and hybridized to a mouse gene expression microarray containing 44.000 features (Figure 1A). After hybridization, 43.020 features, encompassing 33.274 unique identifiers passed our detection criteria to be included in the gene expression analysis. The total change in gene expression as a consequence of Sindbis transduction was substantial: $27.5 \%$ of identifiers at $24 \mathrm{~h}$ and $19.1 \%$ at $72 \mathrm{~h}$ after transduction were significantly 
A

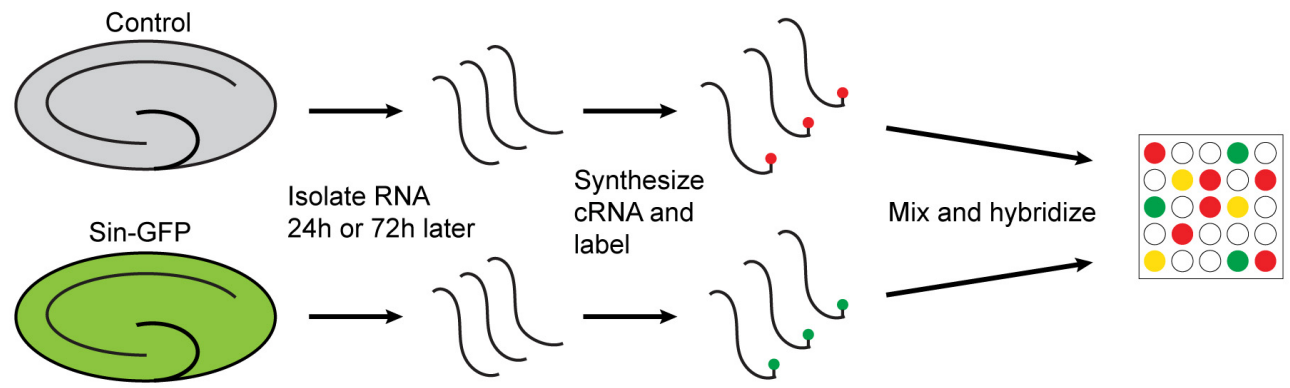

B Not significant FDR-adjusted $\mathrm{P}$ Value $<0.05$

- FDR-adjusted P Value $<0.05$ and $\geq 2$-fold change
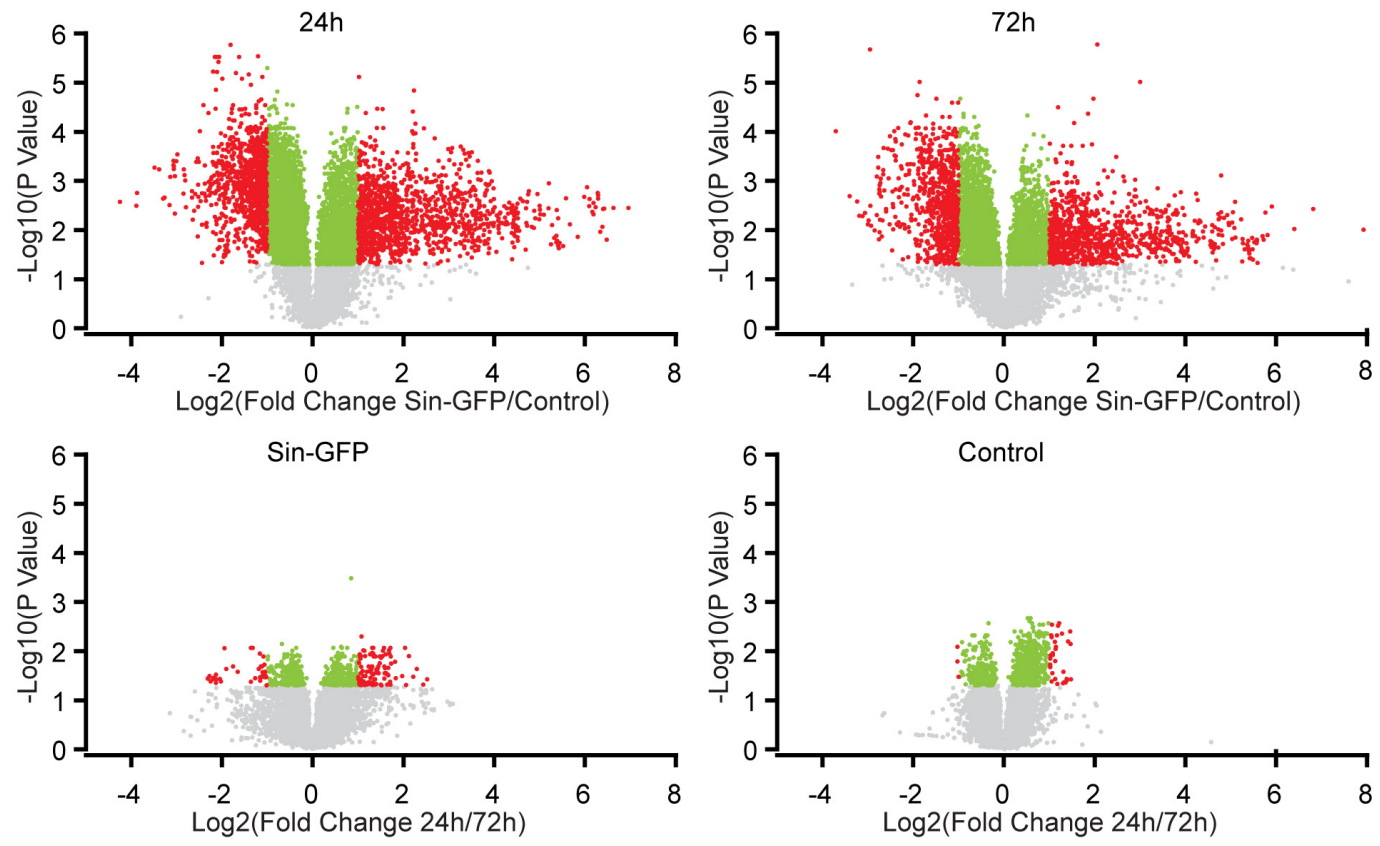

C

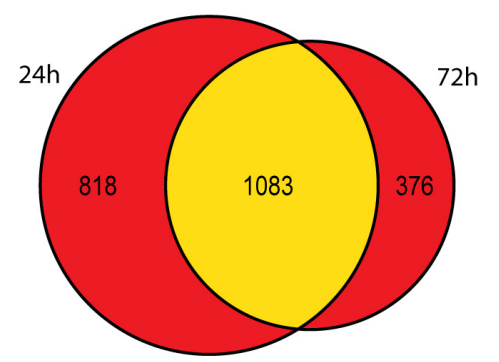

Transcripts changing in a single time point

Transcripts changing in both time points

FIGURE 1 | Gene expression changes in mouse hippocampal slices caused by Sindbis transduction. (A) Schematic workflow (see methods): Organotypic hippocampal slices were injected with PBS containing Sindbis-eGFP $(n=6)$ or with PBS $(n=6)$ as a control, and 24 or $72 \mathrm{~h}$ after injection RNA was isolated, labeled and hybridized to a mouse gene expression microarray. (B) Comparisons in gene expression between Sindbis-GFP and control samples at $24 \mathrm{~h}$ (upper left panel) and $72 \mathrm{~h}$ (upper right panel); and comparisons between 24 and $72 \mathrm{~h}$ for Sindbis-GFP treated samples (lower left panel) and for control treated samples (lower right panel). Volcano plots show fold change in gene expression (Log2) against Benjamini-Hochberg corrected $p$-value (-Log10) for individual features on the microarray. Transcripts that do not pass the significance threshold $(p<0.05)$ are shown in grey, those that changed significantly $<2$-fold are shown in green, and those that changed significantly $\geq 2$-fold are shown in red. (C) Venn diagram showing the overlap between the transcripts that change levels more than 2 -fold at $24 \mathrm{~h}$ and $72 \mathrm{~h}$ of Sindbis treatment compared to control treatment.

altered between transduced and control tissue. To gain insight into the major types of biological processes that were altered upon Sindbis transduction, we performed Gene Ontology (GO) over-representation and pathway analyses using
Panther GO-Slim and Panther Pathways (Thomas et al., 2003; Mi et al., 2009). For this gene ontology analysis, we selected the transcripts that significantly changed by more than 2fold, which represents $5,7 \%$ of identifiers at $24 \mathrm{~h}$ and $4.4 \%$ at 
$72 \mathrm{~h}$ after transduction (Figure 1B). A substantial number of gene expression alterations overlapped between 24 and $72 \mathrm{~h}$ conditions (Figure 1C). GO classes with an FDR-corrected $P$-value of $<0.05$ were considered significant (Tables 1, 2).
At both 24 and $72 \mathrm{~h}$ time points, the genes whose expression was most significantly altered between the Sindbis treated and control groups are strongly associated with gene groups involved in immunological processes (e.g., "Cytokine activity,"

TABLE 1 | Gene Ontology analysis of genes that changed $\geq 2$-fold significantly (FDR-corrected $p<0.05$ ) upon 24 h of Sindbis-GFP treatment compared to control.

\begin{tabular}{|c|c|c|c|c|c|c|c|}
\hline \multirow[b]{2}{*}{ ID } & \multicolumn{6}{|c|}{$\begin{array}{l}\text { Pathways, Molecular Function and Biological Process identifiers that are enriched in the set of genes that } \\
\text { are regulated by } 24 \mathrm{~h} \text { of Sindbis transduction }\end{array}$} & \multirow[b]{2}{*}{ FDR } \\
\hline & Term & Annotated & Regulated & Expected & Fold Enrichment & Raw $P$-value & \\
\hline \multicolumn{8}{|l|}{ Pathways } \\
\hline P00031 & $\begin{array}{l}\text { Inflammation mediated by } \\
\text { chemokine and cytokine } \\
\text { signaling pathway }\end{array}$ & 187 & 39 & 14.49 & 2.69 & 3.11E-07 & $2.52 \mathrm{E}-05$ \\
\hline P00006 & Apoptosis signaling pathway & 80 & 21 & 6.2 & 3.39 & $8.24 \mathrm{E}-06$ & 4.45E-04 \\
\hline P00054 & Toll receptor signaling pathway & 39 & 13 & 3.02 & 4.3 & $5.82 \mathrm{E}-05$ & 2.36E-03 \\
\hline \multicolumn{8}{|c|}{ Molecular function } \\
\hline GO:0003824 & Catalytic activity & 3107 & 331 & 240.82 & 1.37 & 1.70E-09 & 3.14E-07 \\
\hline GO:0005515 & Protein binding & 1855 & 199 & 143.78 & 1.38 & 6.86E-06 & 2.54E-04 \\
\hline GO:0005125 & Cytokine activity & 106 & 25 & 8.22 & 3.04 & 5.98E-06 & 2.77E-04 \\
\hline GO:0016491 & Oxidoreductase activity & 462 & 67 & 35.81 & 1.87 & 4.83E-06 & $2.98 \mathrm{E}-04$ \\
\hline GO:0016787 & Hydrolase activity & 1350 & 152 & 104.64 & 1.45 & $9.88 \mathrm{E}-06$ & 3.05E-04 \\
\hline GO:0008009 & Chemokine activity & 24 & 10 & 1.86 & 5.38 & $9.48 \mathrm{E}-05$ & $2.51 \mathrm{E}-03$ \\
\hline GO:0005102 & Receptor binding & 625 & 78 & 48.44 & 1.61 & 1.27E-04 & 2.95E-03 \\
\hline GO:0008233 & Peptidase activity & 306 & 44 & 23.72 & 1.86 & $3.20 \mathrm{E}-04$ & $6.58 \mathrm{E}-03$ \\
\hline GO:0005488 & Binding & 3686 & 337 & 285.7 & 1.18 & 8.97E-04 & $1.38 \mathrm{E}-02$ \\
\hline GO:0005126 & Cytokine receptor binding & 55 & 13 & 4.26 & 3.05 & $9.83 \mathrm{E}-04$ & $1.40 \mathrm{E}-02$ \\
\hline GO:0005243 & Gap junction channel activity & 19 & 7 & 1.47 & 4.75 & $1.91 \mathrm{E}-03$ & 2.53E-02 \\
\hline \multicolumn{8}{|c|}{ Biological process } \\
\hline GO:0002376 & Immune system process & 525 & 88 & 40.69 & 2.16 & $4.02 \mathrm{E}-10$ & $1.40 \mathrm{E}-08$ \\
\hline GO:0034341 & Response to interferon-gamma & 44 & 20 & 3.41 & 5.86 & $1.08 \mathrm{E}-08$ & 3.29E-07 \\
\hline GO:0065009 & $\begin{array}{l}\text { Regulation of molecular } \\
\text { function }\end{array}$ & 313 & 55 & 24.26 & 2.27 & $1.97 \mathrm{E}-07$ & 5.33E-06 \\
\hline GO:0050790 & Regulation of catalytic activity & 263 & 46 & 20.38 & 2.26 & $3.22 \mathrm{E}-06$ & $6.52 \mathrm{E}-05$ \\
\hline GO:0019221 & $\begin{array}{l}\text { Cytokine-mediated signaling } \\
\text { pathway }\end{array}$ & 40 & 15 & 3.1 & 4.84 & $5.02 \mathrm{E}-06$ & $9.38 \mathrm{E}-05$ \\
\hline GO:0016032 & Viral process & 11 & 7 & 0.85 & 8.21 & $1.54 \mathrm{E}-04$ & 2.67E-03 \\
\hline GO:0000165 & MAPK cascade & 240 & 37 & 18.6 & 1.99 & $2.38 \mathrm{E}-04$ & $3.61 \mathrm{E}-03$ \\
\hline GO:0006520 & $\begin{array}{l}\text { Cellular amino acid metabolic } \\
\text { process }\end{array}$ & 186 & 31 & 14.42 & 2.15 & $2.68 \mathrm{E}-04$ & $3.84 \mathrm{E}-03$ \\
\hline GO:0040011 & Locomotion & 248 & 37 & 19.22 & 1.92 & 4.49E-04 & $5.74 \mathrm{E}-03$ \\
\hline GO:0006950 & Response to stress & 488 & 60 & 37.82 & 1.59 & 9.97E-04 & 1.15E-02 \\
\hline GO:0032502 & Developmental process & 1063 & 114 & 82.39 & 1.38 & $9.94 \mathrm{E}-04$ & $1.21 \mathrm{E}-02$ \\
\hline GO:0006629 & Lipid metabolic process & 361 & 47 & 27.98 & 1.68 & 1.27E-03 & $1.41 \mathrm{E}-02$ \\
\hline GO:0009063 & $\begin{array}{l}\text { Cellular amino acid catabolic } \\
\text { process }\end{array}$ & 50 & 12 & 3.88 & 3.1 & $1.36 \mathrm{E}-03$ & $1.44 \mathrm{E}-02$ \\
\hline GO:0019220 & $\begin{array}{l}\text { Regulation of phosphate } \\
\text { metabolic process }\end{array}$ & 351 & 46 & 27.21 & 1.69 & $1.50 \mathrm{E}-03$ & $1.52 \mathrm{E}-02$ \\
\hline GO:0006955 & Immune response & 296 & 39 & 22.94 & 1.7 & 2.65E-03 & 2.47E-02 \\
\hline GO:0006968 & Cellular defense response & 84 & 16 & 6.51 & 2.46 & $2.56 \mathrm{E}-03$ & 2.49E-02 \\
\hline GO:0006928 & Cellular component movement & 350 & 44 & 27.13 & 1.62 & 3.93E-03 & $3.41 \mathrm{E}-02$ \\
\hline GO:0009605 & Response to external stimulus & 300 & 39 & 23.25 & 1.68 & 3.83E-03 & 3.44E-02 \\
\hline GO:0030097 & Hemopoiesis & 11 & 5 & 0.85 & 5.86 & 4.27E-03 & $3.58 \mathrm{E}-02$ \\
\hline GO:0007399 & Nervous system development & 218 & 30 & 16.9 & 1.78 & $5.87 \mathrm{E}-03$ & 4.60E-02 \\
\hline GO:0006796 & $\begin{array}{l}\text { Phosphate-containing } \\
\text { compound metabolic process }\end{array}$ & 1084 & 110 & 84.02 & 1.31 & $6.15 \mathrm{E}-03$ & 4.67E-02 \\
\hline
\end{tabular}

Fisher's exact test with FDR correction was performed. Annotated = number of genes on the array with a specific identifier. Regulated $=$ number of genes in the list of regulated genes with a specific identifier. Expected = number of genes with a specific identifier that is expected to occur in the list of regulated genes, if the regulated genes were a random subset of the annotated genes. 
TABLE 2 | Gene Ontology analysis of genes that changed $\geq 2$-fold significantly (FDR-corrected p < 0.05) upon 72h of Sindbis-GFP treatment compared to control.

\begin{tabular}{|c|c|c|c|c|c|c|c|}
\hline \multicolumn{8}{|c|}{$\begin{array}{l}\text { Pathways, Molecular Function and Biological Process identifiers that are enriched in the set of genes that } \\
\text { are regulated by } 72 \mathrm{~h} \text { of Sindbis transduction }\end{array}$} \\
\hline ID & Term & Annotated & Regulated & Expected & Fold enrichment & Raw $P$-value & FDR \\
\hline \multicolumn{8}{|l|}{ Pathways } \\
\hline P00031 & $\begin{array}{l}\text { Inflammation mediated by } \\
\text { chemokine and cytokine } \\
\text { signaling pathway }\end{array}$ & 187 & 33 & 11.23 & 2.94 & $2.78 \mathrm{E}-07$ & 2.25E-05 \\
\hline P00006 & Apoptosis signaling pathway & 80 & 15 & 4.8 & 3.12 & 2.77E-04 & 1.12E-02 \\
\hline \multicolumn{8}{|c|}{ Molecular function } \\
\hline GO:0003824 & Catalytic activity & 3107 & 258 & 186.58 & 1.38 & 4.02E-08 & 3.72E-06 \\
\hline GO:0016787 & Hydrolase activity & 1350 & 128 & 81.07 & 1.58 & 8.03E-07 & 3.72E-05 \\
\hline GO:0005515 & Protein binding & 1855 & 165 & 111.39 & 1.48 & $6.64 \mathrm{E}-07$ & 4.09E-05 \\
\hline GO:0005125 & Cytokine activity & 106 & 21 & 6.37 & 3.3 & 8.72E-06 & 3.23E-04 \\
\hline GO:0016788 & $\begin{array}{l}\text { Hydrolase activity, acting on } \\
\text { ester bonds }\end{array}$ & 388 & 43 & 23.3 & 1.85 & 2.89E-04 & 5.34E-03 \\
\hline GO:0005243 & Gap junction channel activity & 19 & 7 & 1.14 & 6.14 & 4.65E-04 & 7.82E-03 \\
\hline GO:0008233 & Peptidase activity & 306 & 35 & 18.38 & 1.9 & 7.73E-04 & 1.19E-02 \\
\hline GO:0016491 & Oxidoreductase activity & 462 & 47 & 27.74 & 1.69 & 8.71E-04 & 1.24E-02 \\
\hline GO:0005509 & Calcium ion binding & 144 & 20 & 8.65 & 2.31 & 1.06E-03 & 1.39E-02 \\
\hline GO:0000166 & Nucleotide binding & 115 & 16 & 6.91 & 2.32 & 3.46E-03 & 3.77E-02 \\
\hline GO:0005126 & Cytokine receptor binding & 55 & 10 & 3.3 & 3.03 & 3.39E-03 & 3.92E-02 \\
\hline \multicolumn{8}{|c|}{ Biological process } \\
\hline GO:0002376 & Immune system process & 525 & 79 & 31.53 & 2.51 & $2.20 \mathrm{E}-12$ & $1.78 \mathrm{E}-10$ \\
\hline GO:0034341 & Response to interferon-gamma & 44 & 17 & 2.64 & 6.43 & 2.77E-08 & 1.35E-06 \\
\hline GO:0050790 & Regulation of catalytic activity & 263 & 33 & 15.79 & 2.09 & 1.88E-04 & 3.05E-03 \\
\hline GO:0065009 & $\begin{array}{l}\text { Regulation of molecular } f \\
\text { unction }\end{array}$ & 313 & 37 & 18.8 & 1.97 & 2.43E-04 & 3.70E-03 \\
\hline GO:0016337 & Cell-cell adhesion & 115 & 18 & 6.91 & 2.61 & 5.08E-04 & 7.27E-03 \\
\hline GO:0032502 & Developmental process & 1063 & 92 & 63.83 & 1.44 & $7.28 \mathrm{E}-04$ & 9.82E-03 \\
\hline GO:0006629 & Lipid metabolic process & 361 & 39 & 21.68 & 1.8 & $9.10 \mathrm{E}-04$ & 1.11E-02 \\
\hline GO:0040011 & Locomotion & 248 & 30 & 14.89 & 2.01 & 8.75E-04 & 1.12E-02 \\
\hline GO:0006636 & $\begin{array}{l}\text { Unsaturated fatty acid } \\
\text { biosynthetic process }\end{array}$ & 5 & 4 & 0.3 & 13.32 & 1.02E-03 & 1.13E-02 \\
\hline GO:0009063 & $\begin{array}{l}\text { Cellular amino acid catabolic } \\
\text { process }\end{array}$ & 50 & 10 & 3 & 3.33 & 1.84E-03 & 1.87E-02 \\
\hline GO:0006955 & Immune response & 296 & 32 & 17.77 & 1.8 & 2.42E-03 & $2.18 \mathrm{E}-02$ \\
\hline GO:0035556 & Intracellular signal transduction & 789 & 69 & 47.38 & 1.46 & 2.97E-03 & 2.58E-02 \\
\hline GO:0006633 & Fatty acid biosynthetic process & 57 & 10 & 3.42 & 2.92 & 4.25E-03 & 3.56E-02 \\
\hline GO:0007399 & Nervous system development & 218 & 25 & 13.09 & 1.91 & 4.51E-03 & 3.65E-02 \\
\hline GO:0006520 & $\begin{array}{l}\text { Cellular amino acid metabolic } \\
\text { process }\end{array}$ & 186 & 22 & 11.17 & 1.97 & 5.69E-03 & 4.46E-02 \\
\hline
\end{tabular}

Fisher's exact test with FDR correction was performed. Annotated = number of genes on the array with a specific identifier. Regulated = number of genes in the list of regulated genes with a specific identifier. Expected = number of genes with a specific identifier that is expected to occur in the list of regulated genes, if the regulated genes were a random subset of the annotated genes. 
"Chemokine activity," "Response to interferon-gamma"). These results suggest that massive exposure to Sindbis viral vectors evokes cytokine and chemokine mediated innate immune responses in hippocampal slice cultures.

In addition, biological process categories that seem unrelated to post-mitotic neurons, such as "Cell proliferation," "Locomotion" and "Macrophage activation," were overrepresented when Sindbis treated cultured hippocampal slices were compared to control treated slices at either 24 or $72 \mathrm{~h}$ post-injection. In response to injury or pathogen invasion, quiescent ramified microglia proliferate and transform into reactive microglia (Kreutzberg, 1996; Stence et al., 2001). We specifically investigated the commonly used reactive microglia markers CD40 antigen, CD68 antigen, Cx3cr1, Icam1, and Tmem119 to see whether these were upregulated in Sindbis treated slices, as would be expected from microglial activation (Streit et al., 1989; Graeber and Streit, 1990; Slepko and Levi, 1996; Benveniste et al., 2001). Indeed, levels of CD40, CD68, and Icam 1 were increased at both 24 and $72 \mathrm{~h}$ after transduction. Tmem119 levels were unaffected at $24 \mathrm{~h}$, however, showed a significant increase at $72 \mathrm{~h}$. Astrocyte markers such as Gfap, S100 beta, vimentin and Aldh1a1 that are associated with reactive astrocytes were decreased. These data suggest that a proportion of gene expression changes might be due to the activation of glial cells. Notably, genes classified in the "Apoptosis signaling pathway" were overrepresented at both 24 and $72 \mathrm{~h}$ time points post-Sindbis transduction (Tables 1, 2). This may indicate that the exposure to Sindbis vectors triggers apoptotic cell death in cultured slices. However, we cannot distinguish whether this involves apoptosis signaling in glia or neurons.

We also measured gene expression changes over time. The comparison of $24 \mathrm{~h}$ and $72 \mathrm{~h}$ of Sindbis transduction yielded 101 genes that were at least 2-fold up- or down-regulated (75 up and 26 down) (Figure 1B). This list corresponds to $0.3 \%$ of the total genes detected in the microarray, and shows over-representation of the Pathways identifier "Inflammation mediated by chemokine and cytokine signaling pathway" (Table 3), suggesting an evolving immune response between 24 and $72 \mathrm{~h}$. The comparison of 24 and $72 \mathrm{~h}$ of control treatment yielded 32 genes $(0.1 \%$ of the total amount of genes) that were at least 2-fold up- or down-regulated (29 up and 3 down) (Figure 1B), possibly reflecting maturation or aging of hippocampal cells in organotypic slices.

\section{Effects of Sindbis-GFP Transduction on the Proteome}

To establish insight into protein expression profiles that change as a consequence of Sindbis transduction, a proteomic analysis was performed. Organotypic slices of the mouse hippocampus were injected with Sindbis viral vector expressing eGFP (50$100 \%$ of cells $\mathrm{GFP}^{+}$) or control-treated, and at 24 or $72 \mathrm{~h}$ post-injection total protein fractions were isolated, in-gel trypsin digested and analyzed by liquid chromatography tandem mass spectrometry (LC-MS/MS) (Figure 2A). For identification of peptides originating from both mouse and Sindbis, the obtained data were searched against their respective FASTA files. In total 20.559 and 19.844 peptides were identified, encompassing 2.919 and 2.792 proteins in the 24 and $72 \mathrm{~h}$ dataset, respectively. As expected, GFP was detected in the Sindbis injected slices, but not in control slices. Since the viral vecors are replication deficient, Sindbis structural and non-structural polyproteins are not produced by Sindbis-transduced cells. However, these polyproteins remained detectable in organotypic slices up to $72 \mathrm{~h}$ post-injection (Table 4), indicating viral vector particles were still present in organotypic slices. Besides these Sindbisrelated proteins, a set of immune-related proteins were only found expressed in slices injected with viral vectors (and therefore cannot be statistically compared), which were more numerous at $72 \mathrm{~h}$ than at $24 \mathrm{~h}$ (Table 4). These include proteins involved in virus detection and interferon induction (DDX58, HA1L), key transcription factors activated by interferons $(S T A T 1 / 2)$ and other interferon-stimulated proteins (IFIT1/2/3, ISG15, ICAM1, GBP2, IIGP1, and IGTP). Together, these protein level changes are reminiscent of an anti-viral innate immune response in brain tissue (Fensterl and Sen, 2014; Hidano et al., 2016; Miller et al., 2016).

For statistical analysis, we proceeded with proteins that were detected in at least half of the samples per condition. At $24 \mathrm{~h}$, out of 1.671 detectable proteins none showed significant regulation by Sindbis viral vector after FDR correction $($ FDR $=0.05)$

TABLE 3 | Gene Ontology analysis of genes that changed $>$ 2-fold significantly (FDR-corrected $p<0.05$ ) between 24h and 72h of Sindbis-GFP treatment.

Pathways, Molecular Function and Biological Process identifiers that are enriched in the set of genes that are regulated between 24 and $72 \mathrm{~h}$ of Sindbis transduction

\begin{tabular}{|c|c|c|c|c|c|c|c|}
\hline ID & Term & Annotated & Regulated & Expected & Fold Enrichment & Raw $P$-value & FDR \\
\hline \multicolumn{8}{|l|}{ Pathways } \\
\hline P00031 & $\begin{array}{l}\text { Inflammation mediated by } \\
\text { chemokine and cytokine } \\
\text { signaling pathway }\end{array}$ & 187 & 6 & 0.86 & 6.95 & $2.55 E-04$ & 4.14E-02 \\
\hline \multicolumn{8}{|c|}{ Biological Process } \\
\hline GO:0002376 & Immune system process & 525 & 11 & 2.43 & 4.54 & 3.01 E-05 & 7.32E-03 \\
\hline
\end{tabular}

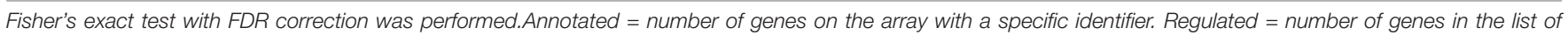

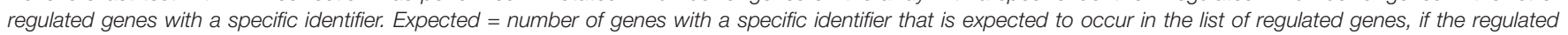
genes were a random subset of the annotated genes. 


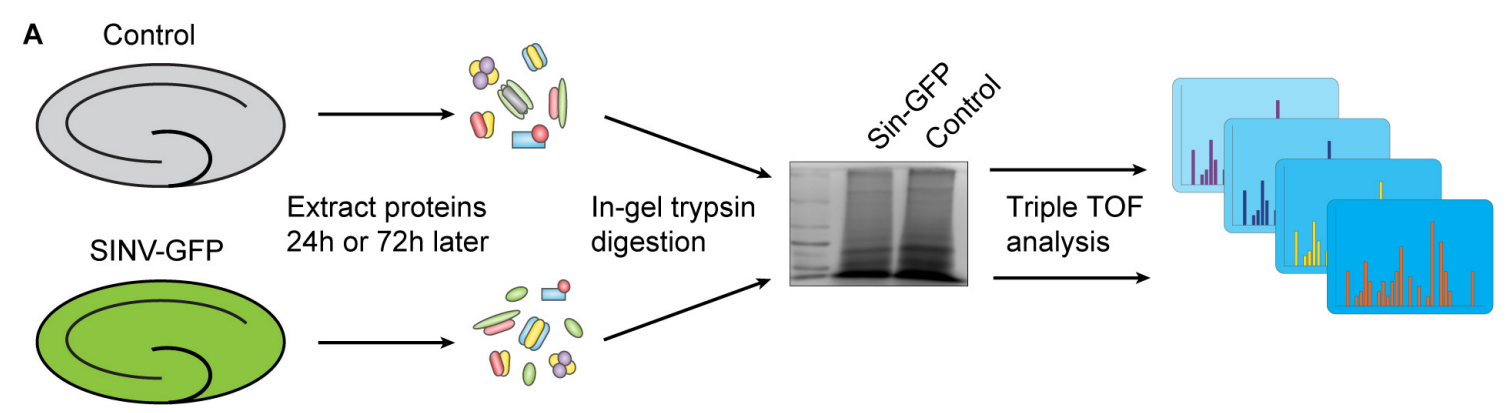

Not significant FDR-adjusted $\mathrm{P}$ Value $<0.05$ FDR-adjusted $\mathrm{P}$ Value $<0.05$ and $\geq 2$-fold change
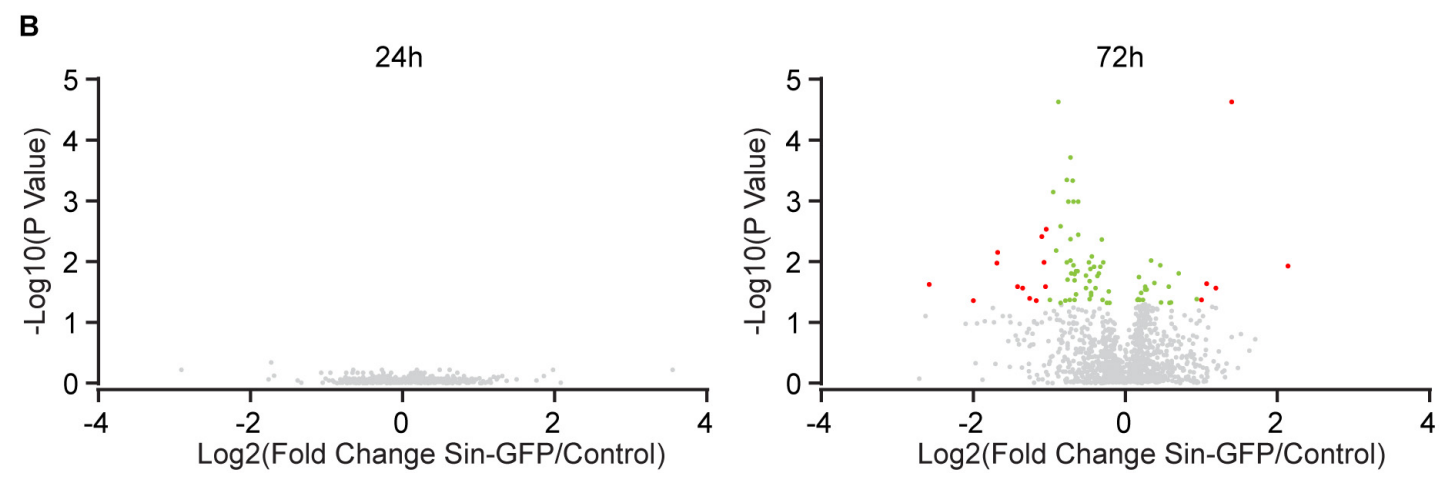

FIGURE 2 | Protein expression changes caused by Sindbis transduction. (A) Schematic workflow (see methods): Organotypic hippocampal slices were injected with Sindbis-GFP $(n=6)$ or control treated $(n=5)$, and analyzed 24 or $72 \mathrm{~h}$ after injection. (B) Comparisons in protein expression between Sindbis-GFP and control samples at 24h (left panel) and 72h (right panel). Volcano plots show fold change in gene expression (Log2) against Benjamini-Hochberg corrected $p$-value (-Log10) for individual proteins. Proteins that do not pass the significance threshold $(p<0.05)$ are shown in grey, those that change significantly by $<2$-fold are shown in green, and those that change significantly by $\geq 2$-fold are shown in red.

(Figure 2B). At $72 \mathrm{~h}$, out of 1.619 proteins, 84 proteins showed significant regulation at an FDR of 0.05 (5.2\% of total; 23 up and 61 down), of which 17 showed significant regulation by at least 2-fold (5 up and 12 down) (Figure 2B). A number of higher expressed proteins are known to be induced by viral infection or interferon signaling (FRIL1 FRIH, VCAM1 and PSME1) (Mulvey et al., 1996; Calabresi et al., 2001). In addition, a number of extracellular matrix and cell adhesion proteins (CSPG5, NCHL1, CTNA1 and NFASC) were lower expressed (Hillenbrand et al., 1999; Drees et al., 2005; Liu et al., 2011; Jin et al., 2018) (Table 4). PANTHER analysis of this list of 84 proteins yielded no significant associations with any known GO or Pathways identifiers. These experiments reveal that changes in protein expression as a consequence of Sindbis transduction were modest compared with gene expression changes, and were predominantly related to anti-viral innate immune responses.

\section{Effects of Sindbis-GFP Transduction on the Electrophysiological Properties}

We next assessed whether Sindbis transduction affected the electrophysiological properties of hippocampal neurons. We made comparisons between Sindbis-transduced CA1 pyramidal neurons and their neighboring non-transduced neurons in the same slice, and between neurons in slices from the same animal that were control treated. In these experiments we transduced organotypic hippocampal slices similarly as for the previous experiments $\left(50-100 \%\right.$ of neurons $\mathrm{GFP}^{+}$) and recorded at regions where $\sim 50-80 \%$ of neurons expressed GFP. Transduced and non-transduced CA1 neurons showed similar resting membrane potential and membrane potential changes across current injections at both the 24 and $72 \mathrm{~h}$ time points (Figures 3B,D). To assess whether Sindbis transduction affects the intrinsic excitability of CA1 neurons, we quantified the firing frequency per incremental current step to establish a frequencycurrent (F-I) relation. The F-I relation of GFP-expressing neurons was similar to that of non-transduced neurons at both $24 \mathrm{~h}$ and $72 \mathrm{~h}$ after injection (Figure 3C), indicating that Sindbis did not affect neuronal excitability. Hyperpolarization of CA1 neurons creates a voltage sag that is characteristic of $\mathrm{HCN}$ channel activation. GFP-expressing CA1 neurons did not show significant changes in sag ratio either at 24 or $72 \mathrm{~h}$ after Sindbis treatment (Figure 3E), indicating that Sindbis did not alter HCN currents.

Previous studies have shown that electrically evoked synaptic currents of CA1 neurons transduced with Sindbis-GFP are on average similar to those of neighboring non-transduced neurons 24-36 h after administration of the Sindbis viral vector (Hayashi et al., 2000; Kamenetz et al., 2003; Marie et al., 2005). To examine this further, we measured miniature excitatory 
TABLE 4 | Proteins that were only detected in Sindbis-GFP treated slices (top), or only detected in control treated slices (middle), or changed $\geq 2$-fold significantly (FDR-corrected $p<0.05$ ) upon Sindbis-GFP treatment compared to control (bottom).

\begin{tabular}{|c|c|c|c|}
\hline Gene name & Protein name & $24 \mathrm{~h}$ & 72 \\
\hline \multicolumn{4}{|c|}{ Proteins detected only in all Sindbis treated samples } \\
\hline Poln & Sindbis non-structural polyprotein & $\checkmark$ & $\checkmark$ \\
\hline Pols & Sindbis structural polyprotein & $\checkmark$ & $\checkmark$ \\
\hline Gfp & Green fluorescent protein & $\checkmark$ & $\checkmark$ \\
\hline Cep55 & Isoform 2 of Centrosomal protein of 55 kDa & $\checkmark$ & \\
\hline Ddx58 & Probable ATP-dependent RNA helicase DDX58 & & $\checkmark$ \\
\hline Gbp2 & Guanylate-binding protein 1 & & $\checkmark$ \\
\hline H2-D1 & $\mathrm{D}(\mathrm{B})$ glycoprotein & & $\checkmark$ \\
\hline Icam1 & Isoform 2 of Intercellular adhesion molecule 1 & & $\checkmark$ \\
\hline Ifit1 & $\begin{array}{l}\text { Interferon-induced protein with tetratricopeptide } \\
\text { repeats } 1\end{array}$ & $\checkmark$ & $\checkmark$ \\
\hline Ifit3 & $\begin{array}{l}\text { Interferon-induced protein with tetratricopeptide } \\
\text { repeats } 3\end{array}$ & $\checkmark$ & \\
\hline I gtp & Protein lgtp & & $\checkmark$ \\
\hline ligpl & $\begin{array}{l}\text { Interferon-gamma-inducible GTPase Ifgga1 } \\
\text { protein }\end{array}$ & & $\checkmark$ \\
\hline Isgl5 & G1p2 protein & & $\checkmark$ \\
\hline Mvp & Major vault protein & & $\checkmark$ \\
\hline Rnf213 & E3 ubiquitin-protein ligase RNF213 & $\checkmark$ & $\checkmark$ \\
\hline Stat1 & Signal transducer and activator of transcription & & $\checkmark$ \\
\hline Stat2 & Signal transducer and activator of transcription & & $\checkmark$ \\
\hline \multicolumn{4}{|c|}{ Proteins detected only in all control treated samples } \\
\hline Atp2b2 & Calcium-transporting ATPase & $\checkmark$ & \\
\hline Endod1 & Endonuclease domain-containing 1 protein & & $\checkmark$ \\
\hline Ptprf & Receptor-type tyrosine-protein phosphatase F & & $\checkmark$ \\
\hline Sparcl1 & SPARC-like protein 1 & $\checkmark$ & $\checkmark$ \\
\hline \multicolumn{4}{|c|}{ Proteins that are changed $\geq 2$-fold significantly } \\
\hline Fth1 & Ferritin heavy chain & & $\checkmark$ \\
\hline Glul & Glutamine synthetase & & $\checkmark$ \\
\hline Plpp3 & Phospholipid phosphatase 3 & & $\checkmark$ \\
\hline Hspb6 & Heat shock protein beta- 6 & & $\checkmark$ \\
\hline Hspb1 & Heat shock protein beta-1 & & $\checkmark$ \\
\hline Chl1 & $\begin{array}{l}\text { Isoform } 2 \text { of Neural cell adhesion molecule } \\
\text { L1-like protein }\end{array}$ & & $\checkmark$ \\
\hline Ftl1 & Ferritin & & $\checkmark$ \\
\hline Psme1 & $\begin{array}{l}\text { Proteasome activator complex subunit } 1 \\
\text { (Fragment) }\end{array}$ & & $\checkmark$ \\
\hline Ctnna1 & Catenin (Cadherin associated protein), alpha 1 & & $\checkmark$ \\
\hline Nfasc & Neurofascin & & $\checkmark$ \\
\hline Llgl1 & Lethal(2) giant larvae protein homolog 1 & & $\checkmark$ \\
\hline Cspg5 & Isoform 2 of Chondroitin sulfate proteoglycan 5 & & $\checkmark$ \\
\hline Vcam1 & Vascular cell adhesion protein 1 & & $\checkmark$ \\
\hline Neo1 & Neogenin & & $\checkmark$ \\
\hline Slc7a14 & Probable cationic amino acid transporter & & $\checkmark$ \\
\hline Aldhla1 & Retinal dehydrogenase 1 & & $\checkmark$ \\
\hline Hist1h1e & Histone $\mathrm{H} 1.4$ & & $\checkmark$ \\
\hline
\end{tabular}

postsynaptic currents (mEPSCs) at 24 or $72 \mathrm{~h}$ after Sindbis treatment. When we recorded $\mathrm{GFP}^{+} \mathrm{CA} 1$ neurons $24 \mathrm{~h}$ after transduction in regions containing $50-80 \% \mathrm{GFP}^{+}$neurons, the average amplitude and frequency of mEPSCs of Sindbistransduced CA1 neurons were not significantly different from

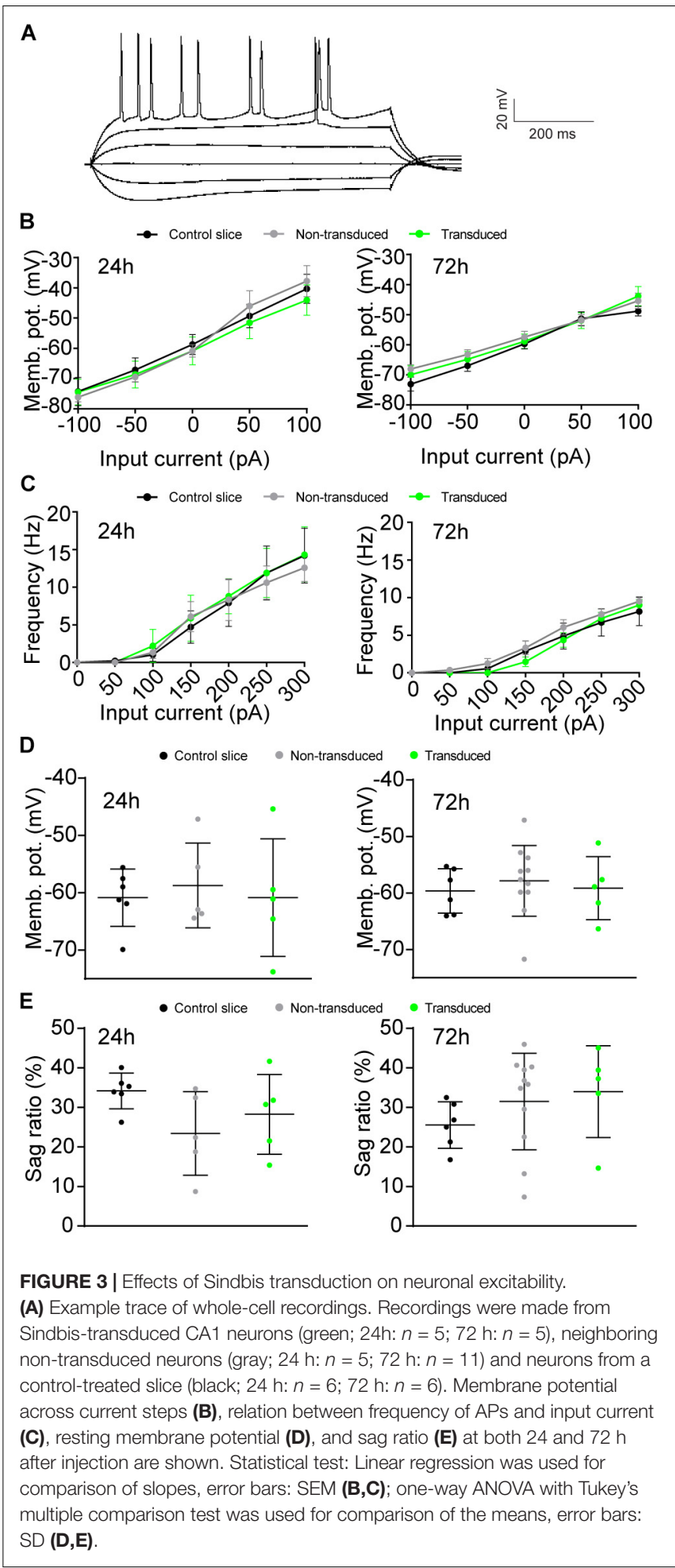

either neighboring non-transduced CA1 neurons, or neurons from a control treated slice (Figures 4A-C). For the $72 \mathrm{~h}$ time point, we tested the effect of Sindbis transduction in CA1 regions at three different transduction rates: low $(<20 \%)$, medium $(20-50 \%)$ and high $(50-80 \%)$ levels of GFP+ CA1 
neurons. For the data from three transduction rates combined, the mEPSC frequency and amplitude of transduced CA1 neurons are similar to those of control-treated neurons (Figures $4 \mathrm{~A}-\mathrm{C}$ ). However, after splitting the data between the low, medium and high transduction rates, we did observe a significant increase in both amplitude and frequency in the high transduction rate group (Figure 4D) These results indicate that Sindbis transduction did not alter the number of active synapses, postsynaptic AMPA-receptor content or presynaptic glutamate release probability, except when neurons were recorded in regions of high $(>50 \%)$ transduction rate and were recorded at $72 \mathrm{~h}$ after transduction.

\section{DISCUSSION}

In this study we analyzed the effects of Sindbis transduction of hippocampal neurons on the transcriptome, proteome and electrophysiological properties. At both 24 and $72 \mathrm{~h}$ after viral vector injection, substantial changes in gene expression were observed. The predominant changes in gene transcription relate to proteins involved in immunological responses, including the type-II interferon (IFN- $\gamma$ ), chemokine and cytokine pathways. At the protein level, the changes were also largely limited to proteins with a role in innate immune responses, although they occurred later (i.e., significantly altered at $72 \mathrm{~h}$ but not at $24 \mathrm{~h}$ ), likely reflecting gene transcription preceding protein translation. The proteome changes were less pronounced compared with transcriptome changes: a large number of genes that showed a significant difference in gene expression upon Sindbis injection were not detected as a significant change on a protein level. This discrepancy may be explained by the notion that gene expression changes are not always accompanied by corresponding changes in protein levels due to post-transcriptional and post-translational regulation (De Sousa Abreu et al., 2009; Taylor et al., 2013).

In the CNS innate immune responses are predominantly mediated by glial cells, which can produce cytokines, interferons and chemokines upon exposure to viral particles (Miller et al., 2016). Our gene expression data demonstrate that glial cells were switched to an activated state when exposed to Sindbis particles. Possibly the changes in gene transcription and protein expression were in large part a consequence of a glia-mediated anti-viral innate immune response. A notable example of genes of which expression was significantly altered upon Sindbis injection without a detectable change in protein levels, are those involved in apoptotic signaling. Our data do not reveal whether these apoptotic genes were expressed in neurons or glial cells. We suspect these changes in apoptotic gene expression may be of glial origin, based on our observations that Sindbis causes an immune response and glial activation. This suspicion is supported by the lack of electrophysiological characteristics indicative of reduced health in GFP-expressing neurons. Possibly glia become activated after they are transduced by Sindbis viral vectors. However, previous studies show that Sindbis viral vectors have high selectivity for neurons over glial cell types

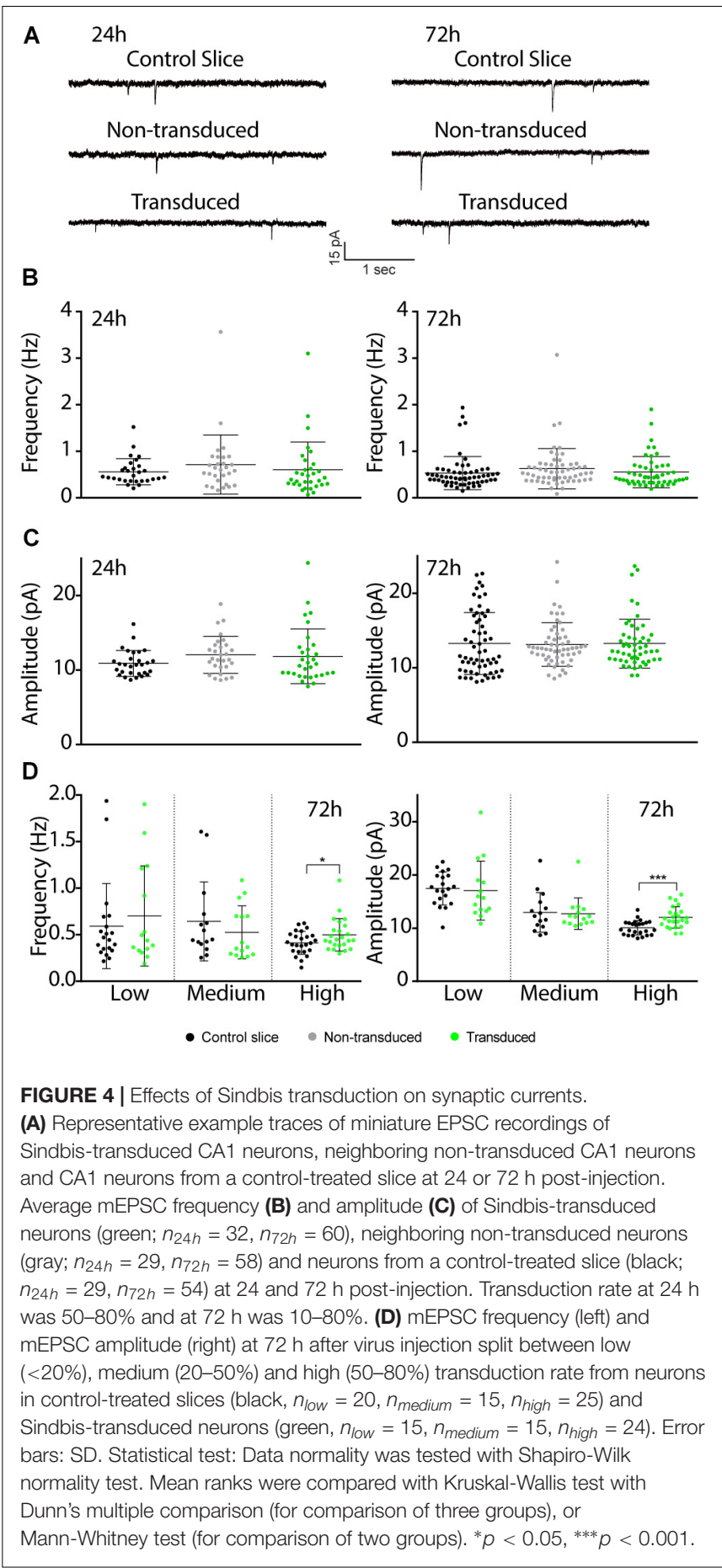

(Ehrengruber et al., 2001). Alternatively, exposure of glia to viral particles may be sufficient to trigger a glial response, or transduced neurons may impact surrounding glial cells. We can also not exclude the possibility that effects we observed are due to immunogenicity of GFP as shown in recent years (Ansari et al., 2016).

Cytokine release upon the induction of an immune response can alter electrophysiological properties of neurons. For instance, 
exposure of neurons to interferons can lead to an increased excitability or to enhanced synaptic currents (Calvet and Gresser, 1979; Vikman et al., 2001; Strauss et al., 2004; Stadler et al., 2014). Similarly, long-term exposure of neurons to the glial tumor necrosis factor alpha (TNF $\alpha$ ) promotes homeostatic scaling of synapse strength upon prolonged exposure (Beattie et al., 2002; Stellwagen and Malenka, 2006). Indeed, at high infection rates Sindbis infection did cause synaptic potentiation after prolonged periods of exposure to Sindbis particles. Notably, synaptic currents remained unaltered when applying low doses of viral particles obtaining fewer than $50 \% \mathrm{GFP}^{+}$neurons, possibly by reducing the strength of the anti-viral immune response. We therefore advocate using sparse $(<50 \%)$ transduction for electrophysiological recordings on Sindbis- transduced neurons to minimize secondary effects on neuronal function due to glial activation and cytokine production. In addition, inclusion of control conditions such as recording neighboring non-transduced neurons and using control vectors is strongly recommended. We do not advocate using Sindbis as a gene transfer method to examine transcriptome changes in cell populations, as the transcriptome is widely affected upon transduction with Sindbis viral particles. However, it is conceivable that lower levels of Sindbis transduction may mitigate these gene expression changes. We conclude that, provided that proper control conditions are included, recombinant Sindbis is a suitable tool for studying

\section{REFERENCES}

Ansari, A. M., Ahmed, A. K., Matsangos, A. E., Lay, F., Born, L. J., Marti, G., et al. (2016). Cellular GFP toxicity and immunogenicity: potential confounders in in vivo cell tracking experiments. Stem Cell Rev. Rep. 12, 553-559. doi: 10.1007/s12015-016-9670-78

Beattie, E. C., Stellwagen, D., Morishita, W., Bresnahan, J. C., Byeong, K. H., Von Zastrow, M., et al. (2002). Control of synaptic strength by glial TNF $\alpha$. Science 295, 2282-2285. doi: 10.1126/science.1067859

Benveniste, E. N., Nguyen, V. T., and O'Keefe, G. M. (2001). Immunological aspects of microglia: relevance to Alzheimer's disease. Neurochem. Int. 39, 381-391. doi: 10.1016/S0197-0186(01)00045-6

Bredenbeek, P. J., Frolov, I., Rice, C. M., and Schlesinger, S. (1993). Sindbis virus expression vectors: packaging of RNA replicons by using defective helper RNAs. J. Virol. 67, 6439-6446.

Calabresi, P. A., Prat, A., Biernacki, K., Rollins, J., and Antel, J. P. (2001). T lymphocytes conditioned with interferon $\beta$ induce membrane and soluble VCAM on human brain endothelial cells. J. Neuroimmunol. 115, 161-167. doi: 10.1016/S0165-5728(01)00253-3

Calvet, M. C., and Gresser, I. (1979). Interferon enhances the excitability of cultured neurones. Nature 278, 558-560. doi: 10.1038/278558a0

D’Apuzzo, M., Mandolesi, G., Reis, G., and Schuman, E. M. (2001). Abundant GFP expression and LTP in hippocampal acute slices by in vivo injection of Sindbis virus. J. Neurophysiol. 86, 1037-1042. doi: 10.1152/jn.2001.86.2.1037

De Sousa Abreu, R., Penalva, L. O., Marcotte, E. M., and Vogel, C. (2009). Global signatures of protein and mRNA expression levels. Mol. Biosyst. 5, 1512-1526. doi: 10.1039/b908315d

Deutsch, E. W., Csordas, A., Sun, Z., Jarnuczak, A., Perez-Riverol, Y., Ternent, T., et al. (2017). The Proteomexchange consortium in 2017: supporting the cultural change in proteomics public data deposition. Nucleic Acids Res. 45, D1100-D1106. doi: 10.1093/nar/gkw936

Drees, F., Pokutta, S., Yamada, S., Nelson, W. J., and Weis, W. I. (2005). $\alpha-$ catenin is a molecular switch that binds E-cadherin- $\beta$-catenin and regulates actin-filament assembly. Cell 123, 903-915. doi: 10.1016/j.cell.2005.09.021 short-term effects of transgene overexpression on neuronal and synaptic function.

\section{DATA AVAILABILITY}

The datasets generated for this study can be found in ProteomeXchange Consortium via the PRIDE partner repository, PXD013634. The microarray datasets are available upon request.

\section{AUTHOR CONTRIBUTIONS}

SU, KB, AS, JV, and HK designed the experiments. SU, SvdS, NR, HX, KL, and HK performed the experiments and analyzed the data. SU and HK wrote the manuscript with input from all authors.

\section{FUNDING}

This work was supported by ZonMw - The Netherlands Organisation for Health Research and Development, grant no. 733050106, dementia Research and Innovation Program "Memorabel" as a part of the "Deltaplan for Dementia."

Ehrengruber, M. U., Hennou, S., Büeler, H., Naim, H. Y., Déglon, N., and Lundstrom, K. (2001). Gene transfer into neurons from hippocampal slices: comparison of recombinant Semliki forest virus, adenovirus, adeno-associated virus, lentivirus, and measles virus. Mol. Cell. Neurosci. 17, 855-871. doi: 10. 1006/mcne.2001.0982

Ehrengruber, M. U., Lundstrom, K., Schweitzer, C., Heuss, C., Schlesinger, S., and Gahwiler, B. H. (1999). Recombinant Semliki forest virus and Sindbis virus efficiently infect neurons in hippocampal slice cultures. Proc. Natl. Acad. Sci. U.S.A. 96, 7041-7046. doi: 10.1073/pnas.96.12.7041

Fensterl, V., and Sen, G. C. (2014). Interferonv induced ifit proteins: their role in viral pathogenesis. J. Virol. 89, 2462-2468. doi: 10.1128/jvi.027442714

Frolov, I., and Schlesinger, S. (1994). Comparison of the effects of Sindbis virus and Sindbis virus replicons on host cell protein synthesis and cytopathogenicity in BHK cells. J. Virol. 68, 1721-1727.

Graeber, M. B., and Streit, W. J. (1990). Microglia: immune network in the CNS. Brain Pathol. 1, 2-5. doi: 10.1111/j.1750-3639.1990.tb00 630.x

Gwag, B. J., Kim, E. Y., Ryu, B. R., Won, S. J., Ko, H. W., Oh, Y. J., et al. (1998). A neuron-specific gene transfer by a recombinant defective Sindbis virus. Mol. Brain Res. 63, 53-61. doi: 10.1016/S0169-328X(98)00251-4

Hayashi, Y., Shi, S. H., Esteban, J. A., Piccini, A., Poncer, J. C., and Malinow, R. (2000). Driving AMPA receptors into synapses by LTP and CaMKII: requirement for GluR1 and PDZ domain interaction. Science 287, 2262-2267. doi: $10.1126 /$ science.287.5461.2262

Hidano, S., Randall, L. M., Dawson, L., Dietrich, H. K., Konradt, C., Klover, P. J., et al. (2016). STAT1 signaling in astrocytes is essential for control of infection in the central nervous system. MBio 7:e01881-16. doi: 10.1128/mBio.01 881-16

Hillenbrand, R., Molthagen, M., Montag, D., and Schachner, M. (1999). The close homologue of the neural adhesion molecule L1 (CHL1): patterns of expression and promotion of neurite outgrowth by heterophilic interactions. Eur. J. Neurosci. 11, 813-826. doi: 10.1046/j.1460-9568.1999.00 496.x 
Jin, J., Tilve, S., Huang, Z., Zhou, L., Geller, H. M., and Yu, P. (2018). Effect of chondroitin sulfate proteoglycans on neuronal cell adhesion, spreading and neurite growth in culture. Neural Regen. Res. 13, 289-297. doi: 10.4103/16735374.226398

Kamenetz, F., Tomita, T., Hsieh, H., Seabrook, G., Borchelt, D., Iwatsubo, T., et al. (2003). APP processing and synaptic function. Neuron 37, 925-937. doi: 10.1016/S0896-6273(03)00124-7

Kebschull, J. M., Garcia da Silva, P., Reid, A. P., Peikon, I. D., Albeanu, D. F., and Zador, A. M. (2016). High throughput mapping of single-neuron projections by sequencing of barcoded RNA. Neuron 91, 975-987. doi: 10.1016/j.neuron.2016. 07.036

Kessels, H. W., Kopec, C. D., Klein, M. E., and Malinow, R. (2009). Roles of stargazin and phosphorylation in the control of AMPA receptor subcellular distribution. Nat. Neurosci. 12, 888-896. doi: 10.1038/nn. 2340

Knafo, S., Sánchez-Puelles, C., Palomer, E., Delgado, I., Draffin, J. E., Mingo, J., et al. (2016). PTEN recruitment controls synaptic and cognitive function in Alzheimer's models. Nat. Neurosci. 19, 443-453. doi: 10.1038/nn. 4225

Kreutzberg, G. W. (1996). Microglia: a sensor for pathological events in the CNS. Trends Neurosci. 19, 312-318. doi: 10.1016/0166-2236(96)100 49-47

Liu, H., Focia, P. J., and He, X. (2011). Homophilic adhesion mechanism of neurofascin, a member of the L1 family of neural cell adhesion molecules. J. Biol. Chem. 286, 797-805. doi: 10.1074/jbc.M110.180281

Malenka, R., and Marie, H. (2006). “Acute”, in Vivo Expression of Recombinant Proteins in Rat Brain Using Sindbis virus. eds J. T. Kittler, and S. J. Moss (Taylor: CRC Press).

Maletic-Savatic, M., Malinow, R., and Svoboda, K. (1999). Rapid dendritic morphogenesis in cal hippocampal dendrites induced by synaptic activity. Science 283, 1923-1927. doi: 10.1126/science.283.5409.1923

Marie, H., Morishita, W., Yu, X., Calakos, N., and Malenka, R. C. (2005). Generation of silent synapses by acute in vivo expression of CaMKIV and CREB. Neuron 45, 741-752. doi: 10.1016/j.neuron.2005.01.039

Mi, H., Dong, Q., Muruganujan, A., Gaudet, P., Lewis, S., and Thomas, P. D. (2009). PANTHER version 7: improved phylogenetic trees, orthologs and collaboration with the gene ontology consortium. Nucleic Acids Res. 38, D204-D210. doi: 10.1093/nar/gkp1019

Miller, K. D., Schnell, M. J., and Rall, G. F. (2016). Keeping it in check: chronic viral infection and antiviral immunity in the brain. Nat. Rev. Neurosci 17, 766-776. doi: $10.1038 / \mathrm{nrn} .2016 .140$

Mulvey, M. R., Kühn, L. C., and Scraba, D. G. (1996). Induction of ferritin synthesis in cells infected with Mengo virus. J. Biol. Chem. 271, 9851-9857. doi: 10.1074/ jbc. 271.16 .9851

Osten, P., Khatri, L., Perez, J. L., Köhr, G., Giese, G., Daly, C., et al. (2000). Mutagenesis reveals a role for ABP/GRIP binding to GluR2 in synaptic surface accumulation of the AMPA receptor. Neuron 27, 313-325. doi: 10.1016/S08966273(00)00039-8

Perez-Riverol, Y., Csordas, A., Bai, J., Bernal-Llinares, M., Hewapathirana, S., Kundu, D. J., et al. (2019). The PRIDE database and related tools and resources in 2019: improving support for quantification data. Nucleic Acids Res. 47, D442-D450. doi: 10.1093/nar/gky1106

Perez-Riverol, Y., Xu, Q.-W., Wang, R., Uszkoreit, J., Griss, J., Sanchez, A., et al. (2016). PRIDE inspector toolsuite: moving toward a universal visualization tool for proteomics data standard formats and quality assessment of proteomexchange datasets. Mol. Cell Proteomics 15, 305-317. doi: 10.1074/ mcp.O115.050229

Reinders, N. R., Pao, Y., Renner, M. C., da Silva-Matos, C. M., Lodder, T. R., Malinow, R., et al. (2016). Amyloid- $\beta$ effects on synapses and memory require AMPA receptor subunit GluA3. Proc. Natl. Acad. Sci. U.S.A. 113, E6526-E6534. doi: $10.1073 /$ pnas. 1614249113

Schlesinger, S. (1993). Alphaviruses - vectors for the expression of heterologous genes. Trends Biotechnol. 11, 18-22. doi: 10.1016/0167-7799(93)90070-P

Slepko, N., and Levi, G. (1996). Progressive activation of adult microglial cells in vitro. Glia 16, 241-246. doi: 10.1002/(sici)1098-1136(199603)16:3<241:: aid-glia6>3.3.co;2-7

Stadler, K., Bierwirth, C., Stoenica, L., Battefeld, A., Reetz, O., Mix, E., et al. (2014). Elevation in type i interferons inhibits $\mathrm{HCN} 1$ and slows cortical neuronal oscillations. Cereb. Cortex 24, 199-210. doi: 10.1093/cercor/bhs305

Stellwagen, D., and Malenka, R. C. (2006). Synaptic scaling mediated by glial TNF- $\alpha$. Nature 440, 1054-1059. doi: 10.1038/nature04671

Stence, N., Waite, M., and Dailey, M. E. (2001). Dynamics of microglial activation: a confocal time-lapse analysis in hippocampal slices. Glia 33, 256-266. doi: 10.1002/1098-1136(200103)33:3<256:AID-GLIA1024<3.0.CO;2-J

Stoppini, L., Buchs, P.-A., and Muller, D. (1991). A simple method for organotypic cultures of nervous tissue. J. Neurosci. Methods 37, 173-182. doi: 10.1016/01650270(91)90128-M

Strauss, U., Mix, E., Rolfs, A., Hadjilambreva, G., and Müller, J. (2004). Neuromodulation by a Cytokine: interferon- $\beta$ differentially augments neocortical neuronal activity and excitability. J. Neurophysiol. 93, 843-852. doi: $10.1152 /$ jn. 01224.2003

Streit, W. J., Graeber, M. B., and Kreutzberg, G. W. (1989). Expression of Ia antigen on perivascular and microglial cells after sublethal and lethal motor neuron injury. Exp. Neurol. 105, 115-126. doi: 10.1016/0014-4886(89)90111-8

Taylor, R. C., Webb Robertson, B. J. M., Markillie, L. M., Serres, M. H., Linggi, B. E., Aldrich, J. T., et al. (2013). Changes in translational efficiency is a dominant regulatory mechanism in the environmental response of bacteria. Integr. Biol. 5, 1393-1406. doi: 10.1039/c3ib40120k

Thomas, P. D., Campbell, M. J., Kejariwal, A., Mi, H., Karlak, B., Daverman, R., et al. (2003). Panther: a library of protein families and subfamilies indexed by function. Genome Res. 13, 2129-2141. doi: 10.1101/gr.772403

Vikman, K. S., Owe-Larsson, B., Brask, J., Kristensson, K. S., and Hill, R. H. (2001). Interferon- $\gamma$-induced changes in synaptic activity and AMPA receptor clustering in hippocampal cultures. Brain Res. 896, 18-29. doi: 10.1016/S00068993(00)03238-8

Wang, F., Zhu, J., Zhu, H., Zhang, Q., Lin, Z., and Hu, H. (2011). Bidirectional control of social hierarchy by synaptic efficacy in medial prefrontal cortex. Science 334, 693-697. doi: 10.1126/science.1209951

Conflict of Interest Statement: The authors declare that the research was conducted in the absence of any commercial or financial relationships that could be construed as a potential conflict of interest.

Copyright (C) 2019 Uyaniker, van der Spek, Reinders, Xiong, Li, Bossers, Smit, Verhaagen and Kessels. This is an open-access article distributed under the terms of the Creative Commons Attribution License (CC BY). The use, distribution or reproduction in other forums is permitted, provided the original author(s) and the copyright owner(s) are credited and that the original publication in this journal is cited, in accordance with accepted academic practice. No use, distribution or reproduction is permitted which does not comply with these terms. 